\begin{tabular}{|c|c|}
\hline & Volume \& Issues Obtainable at The Women University Multan \\
Annals of Social Sciences and Perspective \\
ISSN: 2707-7063, Volume 2, No.2 December 2021
\end{tabular}

\title{
American Muslim Comedians Use of Humour as a Persuasive Agent to Counter Islamophobia
}

\author{
${ }^{1}$ Maryam Mansoor, ${ }^{2}$ Waseem Ishaque, ${ }^{3}$ Mudassir Mukhtar
}

${ }^{1}$ Lecturer, Department of Mass Communication, National University Modern Languages, Islamabad

${ }^{2}$ Assistant Professor, National University Modern Languages Islamabad

${ }^{3}$ Associate Professor/Head Department of Mass Communication, National University of Modern Languages, Islamabad

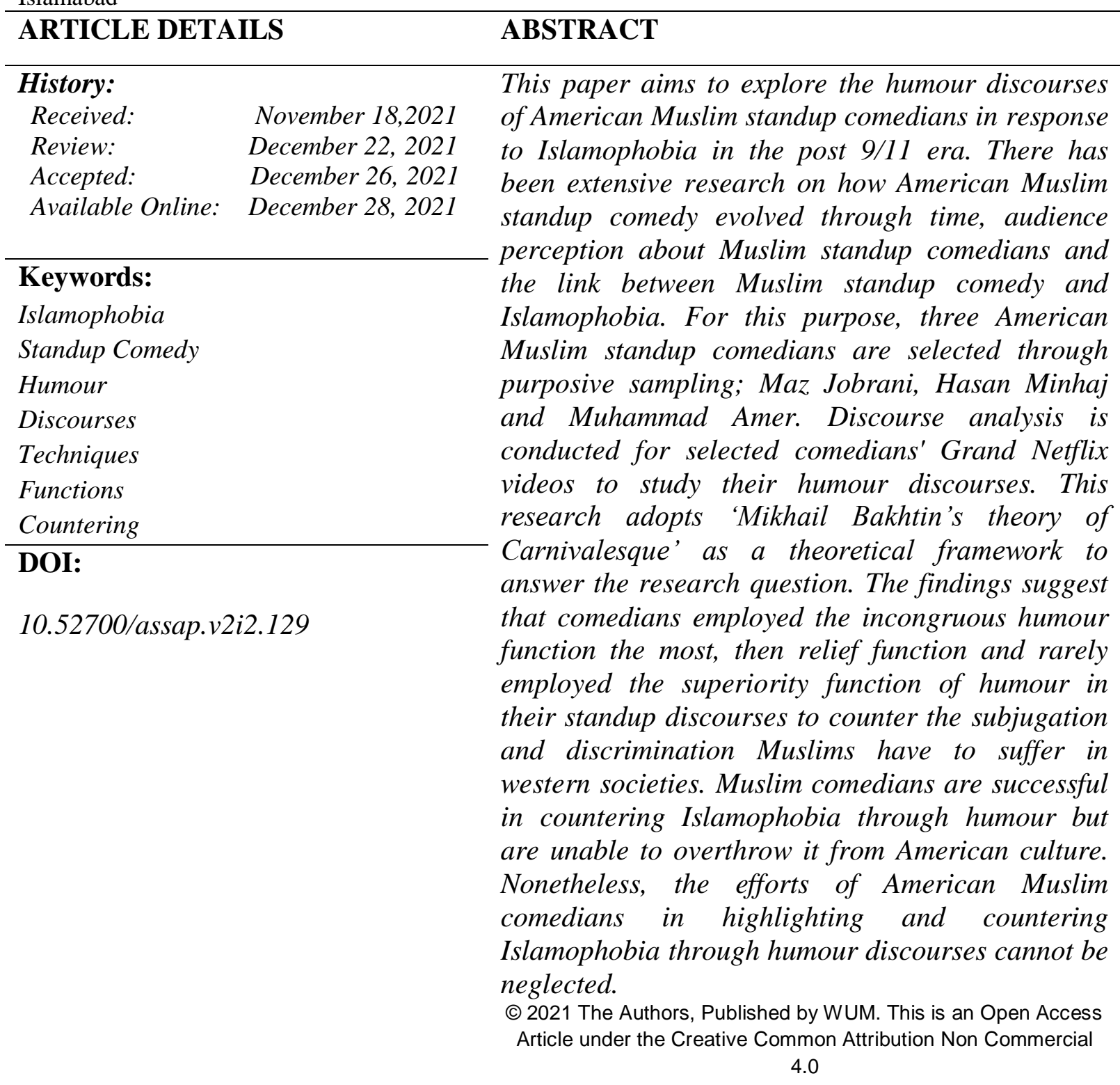

Corresponding author's email address: mmukhtar@numl.edu.pk 


\section{Introduction}

Standup comedy is a special form of the genre of comedy in which the artist who is called the standup comedian gets the microphone and starts telling jokes to the audience directly using short one line jokes, the succession of funny puns and anecdotes (Schwarz, 2009). Using stand-up comedy as a tool to voice against oppressions, to break tensions, to critique and challenge the stereotypes deeply embedded in a culture and to shake the status quo is a very old trend in America and keeping in mind American history it is considered to be the most effective nonviolent form of resistance. This platform has always been used to express real world anxieties (Tuček, 2008).

Muslim comedians continued with the legacy of their predecessors and used humour to critique the culturally embedded Islamophobia specifically after the 9/11 incident. Although the violence against Muslims increased considerably after 9/11 and they have been isolated from the mainstream cultural fabric of American society but the rise of Muslim stand-up comedy is the only good thing associated with the negative charisma of the 9/11 tragedy (Thonnart, 2016). According to Amarasingam (2010), Muslim stand-up comedians have taken the role of organic intellectuals as they are capable of representing their race, defending them and challenging the hegemonic domination of the western world.

According to Zimbardo (2012), Islamophobia is the fear and disliking towards Muslims and Muslim look alike people by the western societies however Beydoun (2018) in his book defines Islamophobia as not only the fear and disliking towards Muslims but also a concept that involves complete erasure of Muslims from the western society. Islamophobia is not limited to Americans only, anyone who places himself against Islam and Muslims is considered as an Islamophobe. Islamophobes think of Muslims as outsiders, violent and Islam as unassimilable.

According to Beydoun (2018), there are two types of Islamophobia, Private Islamophobia and Structural Islamophobia. The former is defined as the hate words, slurs, abuses and violent crimes done on the individual level either by Islamophobes and hatemongers or by institutions that are not directly tied with the state while the latter is defined as the discriminations, prejudices and social injustices against Muslims on the state level by devising such policies like the war on terror policies made by President George Bush and later on carried by Obama and Donald Trump, first and second Muslim banning, patriotic Act, counter radicalization programming and Operation Desert Storm are some of the examples of structural Islamophobia.

Before 9/11 Muslim stand-up comedians were only using humour just for the sake of humour but after the incident Muslim comedians started using comedy with a definitive purpose of undermining the stereotypes that were associated with Muslims. They made use of Gallow humour to address the unjust treatments with them. According to Selim (2014), Muslim and Arab comedians started using humour as a cultural critic soon after the 9/11 tragedy. It officially started with Arab American Comedy Festival in 2003 which was founded by Palestinian American Muslim comedian Maysoon Zayid and Iranian American stand-up comedian Dean Obeidallah. Later on, Allah made me a funny tour, Arabs gone wild and Evil of the Axis comedy tour continued challenging the deeply engraved stereotypes against Muslims in the American culture.

The Incident of 9/1 proved to be the turning point in Muslim stand-up comedy in America. Although this tragedy stirred and highlighted the decades old Islamophobic stereotype perceptions against Muslims it also opened new vistas for Muslim stand-up comedians and 
provided them with a lot of material to talk about on stage. Ironically after 9/11 Muslim stand-up comedians became very popular as Ahmed Ahmed is a well-known American Muslim comedian who used to do terrorist roles in American movies and TV shows however after 9/11 stand-up comedy provided him with an opportunity to challenge the status quo and make his place that he was able to make as he enjoys enormous popularity in America (Bilici, 2010).

Micu (2012) in his paper investigated Arab American standup comedians' performances and their response to Islamophobia through their discourses after the 9/11 incident. To investigate these variables, he chose two video recorded comedy tours named 'Evil of the Axis' and 'Allah made me funny and performed discourse analysis to observe the relationship between Islamophobia and stereotypical representation of Muslims in American culture and media by interpreting results on Mikhail Bakhtin's theory of carnivalesque. He declared at the end that Arab American standup comedy has the dimension of political activism which helps in challenging Islamophobia that is penetrated deep in the American society.

Similarly, Amarasingam (2010) in his paper investigated the Muslim standup discourses in two tours named 'Evil of the Axis' and 'Allah made me Funny'. He adopted the interview method and interviewed some of the Muslim comedians that were part of these two tours, and then performed discourse analysis to interpret the results. He declared that Muslim comedians can be declared as 'organic intellectuals' because they are speaking from the perspective of the oppressed and defending them in the public sphere.

According to Bilici (2010), Muslim ethnic stand-up comedy is considered to be an important part of Americanization. According to him stand-up comedy is quite successful in rehumanizing conceptions about Muslims in American culture and is helpful in the reversal of the existing social order by providing alternative narratives through stand-up comedy. Therefore, it is necessary to analyze their standup discourses to observe how they are responding to Islamophobia through their standup performances, which Islamophobic stereotypes are they countering through their discourses, which humor techniques and humor functions are they employing in their discourses while responding to Islamophobia and to elicit laughter in the audience. This particular study which is drawn from media studies and humor studies will be focused solely on identifying the humor techniques and subject matters in the standup comedians' discourses through discourse analysis.

\subsection{Theories of Humour That Define The Functions Of Humor}

To contextualize the work of above mentioned American Muslim Standup comedians, it is necessary to understand the phenomenon of humour, its theories and techniques which they are employing to counter Islamophobia. The phenomenon of understanding humour in standup comedy isn't complete without the discussion of three basic theories of humour which laid the foundation of standup comedy as Campisano (2016) also said that to understand the context of humour three classical theories of humour must be understood; incongruity theory, the superiority theory and relief theory.

Superiority theory is based on this function of humour as the comedian has to establish his superiority in front of the audience if he has to ridicule others. This theory establishes that humour is a means of power and superiority when it has to express the inferiority of others 
Schwarz, (2009). American standup comedy is filled with such examples where the comedians build the minorities' inferiority by portraying them negatively like blacks and Jews. Self-deprecation technique of humour also comes under superiority theory because the comedian makes himself inferior and the audience superior (Campisano, 2016). According to Campisano (2016), the main purpose of relief theory is to release tension or stress. Relief theory suggests that humour is drawn from the buildup and release of tension. Relief theory highlights the tension releasing function of humour as after 9/11 Muslims had to face dejection so they focused on this function of humour by mocking the stereotypes associated with them. In this situation the performer is the one who is 'stereotyped' and the audience is the 'stereotyper' (Selim, 2016).

According to incongruity theory, the introduction or some part of the joke might build up the audience's expectations as to how it will turn out but the punch line of the joke surprises the audience by uttering something opposite and elicit laughter at the incongruity of the humorous incident. This highlights one of the main features of humour which is 'ambiguity' and according to Freud, the audience has to understand the incongruity established by the comedians before they can react to it. In the case of standup comedy, the incongruity can be created either by something that a comedian says unexpectedly or by subject matter that is initially portrayed in one light but with the course of the joke turns out to be something different from what the audience expected (Campisano, 2016).

The study adopts 'Mikhail Bakhtin's theory of Carnivalesque' as a theoretical framework to answer the research question. This theory provides the framework of understanding the American Muslim comedian's use of standup comedy platform as a tool to culturally critique Islamophobia that is embedded in the ideological foundation of America.

\section{American Muslim Comedians use of Standup Comedy as Bakhtin's Carnivalesque}

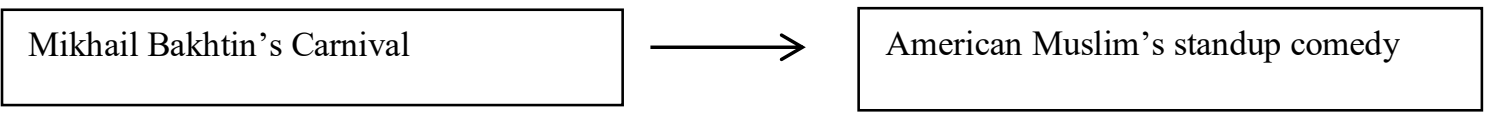

Main concept: Subversion of existing dominant ideologies of the $1^{\text {st }}$ world through carnival discourses

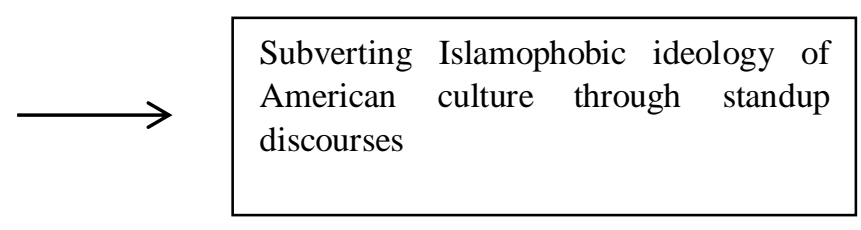

Carnival is a textual mode used to critique and destroy power by laughter

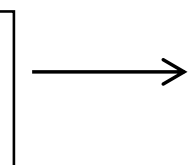

Standup comedy is used by Muslim comedians to culturally critique Islamophobia through humour

Humour is a significant social force (Amarasingam, 2010) and just as humour is used by dominant groups as a weapon of insult; it is also used by minorities as a tool to raise voice 
against social injustice (Zimbardo, 2012). After the 9/11 attack, Muslims suffered hatred remarks and stereotype perceptions from non-Muslims (Micu, 2012). This study aims to find out how American Muslim stand-up comedians are using humour as a persuasive agent to counter Islamophobia in their discourses by incorporating different functions of humour.

The main objectives of this study include;

- To find out how American Muslim comedians are countering Islamophobia by using humour as a tool through stand-up comedy.

- To explore humour theories and functions that American Muslim stand-up comedians are using in their discourses to counter Islamophobia.

- To highlight the efforts of American Muslim stand-up comedians in reversing the anti-Muslim discourses produced by international media by using humour as a cultural critique.

\subsection{Research question}

Q1: "How American Muslim standup comedians are employing humour theories and functions in their discourses to counter Islamophobia"?

\section{Methods}

This study employed mix approach including quantitative but mainly relied on a qualitative method involving the use of discourse analysis to explore the humour discourses of American Muslim standup comedians to observe the humour techniques and functions.

This exploratory research with relatively a small sample size is less structured. As Silverman (2000) said that exploratory studies require a less structured organization as compared to confirmatory studies. This particular study is based on two variables, 'countering Islamophobia' as the dependent variable and 'standup comedy/discourses' being the independent variable as the standup discourses of selected comedians are watched to explore how American Muslim comedians are countering Islamophobia. Operationally 'standup comedy' in this particular study is defined as ' 1 and a half hour long debuted Netflix videos of Hasan Minhaj, Maz Jobrani and Mo Amer' and 'countering Islamophobia' here is defined as 'the Identification of particular humor functions that selected standup comedians are using in their discourses to oppose discriminations and negative stereotypes associated with Muslims in America.

Since this study intends to explore the Humour discourses of American Muslim standup comedians so for this purpose; three American Muslim standup comedians are selected; Hasan Minhaj, Maz Jobrani and Muhammad Amer. They are selected by purposive sampling in which a homogenous sample is selected because these similar sets of cases have to be studied intensively. Their discourses are studied and humour functions they are employing are 
identified from the videos for analysis. The reason why these comedians are chosen is based on their popularity and influence among the audience and because they are among the only few American Muslim standup comedians who debuted on Netflix with their shows. Their videos from Netflix were collected because of two reasons; first, the sample comedians don't have official YouTube channels except for Maz Jobrani, nor do their videos are available on their official websites for free due to country restraints. Secondly, these Netflix shows were these comedians' grand shows which included the short standup routines that they did on different late night shows like Tonight with Jimmy Kimmel and The Daily Show, etc. so it was convenient for the researcher to collect their Grand shows of 1-and-a-half-hour long time duration. Moreover, Netflix increased popularity among the American audience is another reason for data collection from Netflix. It's getting so much popular among the audience that YouTube has introduced YouTube premier as a competitor to Netflix. Hasan Minhaj's grand Netflix show 'The Homecoming King' has 8.3 IMDb ratings; Maz Jobrani's grand Netflix show 'The Immigrant' has 6.6 IMDb ratings and Mo Amer's grand Netflix show "The Vagabond' has 7.3 IMDb ratings. IMDb is the world's most popular online database for information related films, TV programs, games including information about cast, crew, plot, critics and viewers' reviews.

Nvivo that is a widely used software/method for analyzing qualitative data is used for analyzing the data of this particular research as well. After downloading the written transcripts of the whole performances of the selected standup comedians from an online magazine 'scrap from the loft' they are imported into Nvivo. After that, they are separately analyzed by dividing them into particular themes and codes.

First, the whole standup comedy performance of each comedian is watched and two themes were made. First, there is 'discrimination based on religion and the second theme is 'Racism'. After making these two themes; the most frequently used words in selected comedians' discourses are searched through Nvivo. These searched words were "people, immigrants, whites, America, passport, Muhammad, trump, comedy/comedian, parents, Arab, Muslims, Brown, Country, Family, Power, Killing, Travel, Bomb, Airports, Black, Terrorist, Race/Racism, hate crimes". After that, some particular keywords were selected which were then searched for their word frequency in selected comedians' standup discourses through the Nvivo software. These codes were Muslims, racist/racism, immigrants/immigration, passport, airports, Muhammad, Bomb, and Terrorist, killing and hate crimes.

After that with the help of themes and codes, the jokes related to Islamophobia are identified. Then each joke is analyzed separately; first looking at the joke, each joke is analyzed to see which function of humour is employed; either incongruous, relief or superiority. Jokes are categorized into more than one function, as any identified joke can utilize more than one function. To study the humour discourses of the selected comedians, discourse analysis is applied to individual jokes after identifying the jokes related to humour from the selected comedians' standup performances using the themes, then each joke is analyzed for functions each joke is employing. 
The aim of discourse analysts is to study the use of language in a social context. They are concerned with different social contexts of discourses involved in the encoding and decoding of its meanings. This type of analysis reveals the structural and functional approach to language in use where the structural approach focuses on the text while the functional approach focuses on context (Schiffrin, 1994).

Similar is the case with this particular study. The researchers were interested in exploring the humour discourses of selected comedians' standup performances to know the theories of humour which define the functions which are helping them in culturally critiquing and countering Islamophobia therefore analysis method of discourse analysis is opted out for this particular study to answer the research question.

\subsection{Hasan Minhaj:}

Hassan Minhaj is a 32 years old Indian American Muslim stand-up comedian and actor. His genres for comedy are observational, Political/news satire, religion, Islamophobia observational and insult comedy. Hasan Minhaj was the first Muslim and South Asian American to get the opportunity to be the featured speaker at 2017's White House Correspondents dinner. Minhaj got popular and won many awards after his Netflix Debut show 'The Home Coming King'. He was also on the list of 'The Times' magazine 100 most influential people worldwide released in 2019.

Following are the official accounts of Hasan Minhaj on different social networking sites:

Website link: https://hasanminhaj.com/

Facebook page link: https://www.facebook.com/hasanminhaj/

Facebook followers: 527,400

Instagram page link: https://www.instagram.com/hasanminhaj/?hl=en

Instagram followers: 1.5 Million

Twitter link: https://twitter.com/hasanminhaj

Twitter followers: $806 \mathrm{~K}$

\section{Netflix Shows Titles:}

Grand show: The Homecoming King

Weekly show: Patriotic Act with Hasan Minhaj 


\subsection{Maz Jobrani:}

Maz Jobrani is a 46 years Old Iranian American Muslim standup comedian. His subjects for comedy are racism, Islam in the United States, Islamophobia and Iranian culture. Maz Jobrani was one of the members of the 'Evil of the Axis' comedy tour that started in 2005. His standup performances other than 'Evil of the Axis' involves 'Brown and Friendly' (2009), 'I come in peace (2013), 'I'm not a terrorist but I have played one on television (2015) and his Netflix debut standup special named 'Immigrant'. He is one of the only three Muslim standup comedians who debuted with their shows on Netflix.

Following are the official accounts of Maz Jobrani on different social networking sites:

Website link: https://www.mazjobrani.com/

Facebook page link: https://www.facebook.com/mazjobrani/

Facebook followers: $487 \mathrm{~K}$

Instagram page link: https://www.instagram.com/mazjobrani/?hl=en

Instagram followers: $368 \mathrm{~K}$

Twitter link: https://twitter.com/MazJobrani

Twitter followers: $130 \mathrm{~K}$

Netflix Shows Titles:

Grand Show: Immigrant

YouTube Channel: https://www.youtube.com/user/Mazjobrani

YouTube followers: $330 \mathrm{~K}$

\subsection{Mo Amer:}

Muhammad Amer is a 38 years old American Muslim standup comedian of Palestinian descendent. He migrated with his parents and siblings from Kuwait during the gulf war. Muhammad Amer writes and uses his name as Mo Amer. Till now has been interviewed by over more than 100 international media outlets including BBC, CNN, The New York Times and The Guardian. He debuted on Netflix with an hour long standup comedy special named 'The Vagabond' and became one of the only three American Muslim standup comedians who debuted on Netflix along with Maz Jobrani and Hasan Minhaj.

Following are the official accounts of Maz Jobrani on different social networking sites: 
Website link: https://www.moamer.com/

Facebook page link: https://www.facebook.com/realmoamer/

Facebook followers: $56 \mathrm{~K}$

Instagram page link: https://www.instagram.com/realmoamer/?hl=en

Instagram followers: $73.1 \mathrm{~K}$

Twitter link: https://twitter.com/realmoamer

Twitter followers: $19 \mathrm{k}$

\section{Netflix Shows Titles:}

Grand Show: The Vagabond

\section{Findings}

\subsection{Hasan Minhaj's Grand Netflix show 'The Homecoming King'}

Hasan Minhaj's 1 hour 12 minutes long grand Netflix show 'The Homecoming King' includes total of 27 jokes; out of which 18 jokes are related to anti Islamophobia. Hasan Minhaj didn't have a particular anti Islamophobic theme but still, most of his jokes are providing an alternative to the Islamophobia that American Muslims have to endure on daily basis. If we calculate the percentage of 18/27 then around 66.6 percent of Hasan Minhaj's discourse of this grand Netflix show revolves around anti-Islamophobic jokes.

Table 1: Itemization of identified jokes by humour functions Hasan relied on

\begin{tabular}{llclcc}
\hline & & $\begin{array}{l}\text { Incongruous } \\
\text { function }\end{array}$ & $\begin{array}{l}\text { Relief } \\
\text { function }\end{array}$ & $\begin{array}{l}\text { Superiority } \\
\text { function }\end{array}$ & $\begin{array}{l}\text { All three } \\
\text { functions }\end{array}$ \\
\hline $\begin{array}{l}\text { Number of jokes } \\
\text { observed function }\end{array}$ & with & $7 / 18$ & $7 / 18$ & $2 / 18$ & $2 / 18$ \\
\end{tabular}

\begin{tabular}{lllll}
\hline Percentage of identified & $39 \%$ & $39 \%$ & $11.11 \%$ & $11.11 \%$ \\
jokes with observed function & & & &
\end{tabular}


Table1. Interprets that incongruous function is employed in 7 jokes (39\% of 18 jokes in total), relief function is employed in 7 jokes (39\% of 18 jokes in total), superiority function is utilized in 2 jokes (11.11\% of 18 jokes in total) and all three functions are employed in 2 jokes (11.11\% of 18 jokes in total).

\subsection{Muhammad Amer's Grand Netflix show 'The Vagabond'}

Muhammad Amer's 56 minutes long grand Netflix show 'The Vagabond' includes a total of 27 jokes; out of which 21 jokes are related to anti Islamophobia. The main thing to notice is that this Netflix special was just a regular standup discourse of Muhammad Amer, unlike his previous shows which were specifically related to providing an alternative of Islamophobic hate crimes that American Muslims suffer at the hands of whites. Even then most of his jokes in this grand show were anti-Islamophobic. If we calculate the percentage of $21 / 27$ then around 78 percent of Muhammad Amer Netflix's grand show's humour discourse revolves around anti-Islamophobic jokes.

The following table indicates the breakdown of identified jokes of Muhammad Amer's discourse by humour function they relied on:

Table 2: Itemization of identified jokes by humour functions Mo Amer relied on

\begin{tabular}{lllcl}
\hline & $\begin{array}{l}\text { Incongruous } \\
\text { function }\end{array}$ & $\begin{array}{l}\text { Relief } \\
\text { function }\end{array}$ & $\begin{array}{l}\text { Superiority } \\
\text { function }\end{array}$ & $\begin{array}{l}\text { All three } \\
\text { functions }\end{array}$ \\
\hline $\begin{array}{l}\text { Number of jokes with observed } \\
\text { function }\end{array}$ & 4 of 21 & 5 of 21 & 7 of 21 & 5 of 21 \\
& & & &
\end{tabular}

\begin{tabular}{lllll}
\hline Percentage of identified jokes & $19 \%$ & $23 \%$ & $33 \%$ & $23 \%$
\end{tabular}

with observed function

Table2. interprets that incongruous function is employed in 4 jokes (19\% of 21 jokes in total), relief function is employed in 5 jokes ( $23 \%$ of 21 jokes in total), superiority function is utilized in 7 jokes (33\% of 21 jokes in total) and all three functions are employed in 5 jokes (23\% of 21 jokes in total).

\subsection{Maz Jobrani's Grand Netflix show 'The Immigrant'}

Maz Jobrani's 1 hour 7 minutes long grand Netflix show 'Immigrant' includes a total of 42 jokes; out of which 19 jokes are related to anti Islamophobia. The main thing to notice is that this grand show wasn't based on any specific anti-Islamophobic theme; it is a general show which touched every possible subject to elicit humour. However, if we calculate the percentage of 19/42 then around 45.2 percent of Maz Jobrani's humour discourse of this Netflix grand show revolves around anti-Islamophobic jokes. 
Table 3:Itemization of identified jokes by humour functions Jobrani relied on

\begin{tabular}{lcccc}
\hline & $\begin{array}{l}\text { Incongruous } \\
\text { function }\end{array}$ & Relief function & $\begin{array}{l}\text { Superiority } \\
\text { function }\end{array}$ & All three functions \\
$\begin{array}{l}\text { Number of jokes with } \\
\text { observed function }\end{array}$ & $9 / 19$ & $7 / 19$ & $2 / 19$ & $1 / 19$ \\
\hline
\end{tabular}

Table3. interprets that incongruous function is employed in 9 jokes $(47.36 \%$ of 19 jokes in total), relief function is employed in 7 jokes ( $37 \%$ of 19 jokes in total), superiority function is utilized in 2 jokes ( $10.5 \%$ of 19 jokes in total) and all three functions are employed in 1 joke (5.2\% of 19 jokes in total).

\section{Discussion}

In this particular study, the usual standup discourses of selected comedians were analyzed which didn't have a pre-planned theme but still the findings suggested that most of their discourses revolve around anti-Islamophobic jokes that proves two points, first Muslim comedians are following their predecessor comedians footsteps as they are keeping the same old ritual of using stand-up comedy as a tool to counter or challenge status quo, raise voice against oppressions, social evils and inequalities like other immigrants who had problems adjusting in American society (Micu, 2012). This study is proof as most of the sample comedians' humour discourses employ personal narratives to joke about the Islamophobic discriminations they suffer in western societies.

The findings suggest that American Muslim comedians mostly relied on incongruous and relief humour functions and a combination of humour functions to build up the climax and to create punch lines that open up shared understanding of America's underlying Islamophobia and help in destabilizing it by making Islamophobic stereotypes visible and laughable by the audience. This coincides with Selim (2014) study that declared that Muslim comedians are using humour as a cultural critic to challenge or counter Islamophobia since $9 / 11$. The least percentage average employed the superiority function in their discourses.

As per the findings, Hasan Minhaj's discourse mainly relied on the relief function of humour to release the negative tensions and replace these feelings with pleasure and satisfaction which is not only felt by him but the audience as well which is evident through their laughter.

Joke no.6 of his discourse "........ So when 9-11 happened I was in high school. My dad sits everybody down. He's like, "Hasan, whatever you do, do not tell people you're Muslim or talk about politics." "Alright, Dad, I'll just hide it. This just rubs off" (laughter) and another joke "....... Because when it happened, everyone in America felt like their country was under attack. But on that night, September 12th, it was the first night of so many nights where my family's loyalty to this country was under attack. And it always sucks. As immigrants, we 
always have to put on these press releases to prove our patriotism. We're auditioning. "We love this country, please believe me....."(Laughter). Here he used the relief function of humour to narrate the race grievances Muslims had to suffer immediately after 9/11 happened.

In the first mentioned joke Hasan was talking seriously narrating the violent attacks he and his family had to suffer immediately after $9 / 11$ and there was dead silence among the audience then he used the punch line "this just rubs off" by pointing at his brown skin to make the audience laugh that it wasn't that simple for Muslims and nonwhite people to hide their identities because of the brown color. He highlighted the discriminations based on religion and racism against Muslims in a single joke. Similarly, in the second mentioned joke the fact that Muslims had to audition to prove their loyalty to America isn't humorous. However, it is made funny by the comedian through relief function and gestures technique to release the negative energy of being othered and replace it with pleasant emotions by making the audience laugh.

The use of all three functions of humour is evident in Mo Amer's standup. As he started his standup special with this joke "Yes, I am Mo, guys. You know, Mo is short for Mohammed. Surprise, bitches! Today is the day! Your cell phones are locked up. It's too late for you, motherfuckers! Get the door, Aziz! No, I'm just kidding" (Laughter). He made a similar joke 3 times in his Netflix standup and ended his show with a similar joke from a video clip of the live show he did in front of the US troops in Iraq "So my name is Mo. I'm gonna tell you a bit about myself, all right? Take it easy. Are you guys ready? Mo is short for Mohammed. Surprise, bitches! No, I'm kidding. Hey! Put the gun down......."

These jokes not only made the audience laugh but also helped him in highlighting the Islamophobic stereotype that the Muslim name 'Muhammad' is stereotyped as a terrorist or a suicide bomber. The audience laughed at the joke because they understood the context which means they are well aware of the Islamophobic stereotypes that are fed into their minds through international media. He employed the superiority function of humour which means that he made the audience laugh at his expense as he elevated the status of the audience by providing himself as a laughing stock. The fear of Muslims as a potential terrorists is what's creates room for Muslim standup comedy in the world of non-Muslims.

Maz Jobrani's discourse mainly relied on the incongruity function of humour. For example, let's just look at one of his jokes “.....Oh, my God. Speaking of being deported, Trump is president, and... Yeah, I know. I still can't believe it........ I know some of you might've voted for him. I know that some immigrants voted for Trump because they wanted fewer taxes, but they ended up with fewer relatives. Yeah. That happens". (Laughter).

Although the audience laughed due to incongruity they understood the incongruity because they were well aware of the context in which it was made. In this joke Maz Jobrani hinted at the Muslim ban, Trump introduced against Muslims which stopped immigrant Muslims to enter the United States of America and is the biggest example of state level Islamophobia. 
The fact that the immigrants ended up with fewer relatives wasn't funny but the incongruous situation Maz created was what made the audience laugh.

The fact that there is an incongruity between the reality of Muslims in American culture and stereotypes connected to them provides a continuous source of content for Muslim's ethnic humour. The findings of this study show that Muslim American standup comedians are playing an important role in countering or subverting the old age Islamophobic stereotypes by using different functions of humour. However, as the critic of the Carnivalesque approach suggests that it's a temporary transgression where the hierarchies are reversed, and discriminatory practices are mocked for just a time being; similar is the case with Muslim standup comedy. Muslim comedians are successful in countering Islamophobia through humour but are unable to overthrow it from American culture. Nonetheless, the efforts of American Muslim comedians in highlighting and countering Islamophobia through humour discourses cannot be neglected.

\section{Conclusion}

This paper explored how American Muslim comedians counter Islamophobia by incorporating different functions and techniques of humour. This study revealed that the discrepancy between the reality of Muslims and the Islamophobic stereotypes west associates with them automatically create incongruous situations which are narrated and often depicted by American Muslim standup comedians to highlight, subvert and provide the alternative perspective humorously to the American people.

Although this study analyzed the usual standup discourses of Muslim comedians findings suggested that a major portion of their discourses aimed at countering Islamophobic stereotypes. Moreover, many researchers argue that the 9/11 incident provided Muslim comedians with a huge content to talk about on stage so future researchers in this field can compare the humour discourses of Muslim standup comedians before 9/11 and after the 9/11 incident to add value to this particular field of study.

This particular study was confined only to the analysis of humour discourses of selected Muslim comedians due to certain limitations, the future researcher if replicate this study can employ a more enriched methodology of interviews and conduct rhetorical analysis or semiotic analysis to provide another dimension and more comprehensive results of this study.

Another dimension that should be studied by future researchers is the kind of audience that sits across the standup shows of American Muslim standup comedians. It is necessary to closely observe the psychology of live audiences in such shows by sitting across them and to see whether there is a diverse live audience or just Muslims and people from other minority groups who attend the live shows of Muslim standup comedians. Future researchers may also observe the discourses of Muslim comedians from other countries like the UK, Africa, etc. and then compare their discourses to American Muslim standup comedians to spot the 
intensity and types of Islamophobic stereotypes being highlighted and countered by them. This dimension would add value to this particular study.

\section{References}

Adhikary, B. K. (2011). FDI, trade openness, capital formation, and economic growth in Bangladesh: a linkage analysis. International Journal of Business and Management, 6(1), 16-28.

Amarasingam, A. (2010). Laughter the best medicine: Muslim comedians and social criticism in post-9/11 America. Journal of Muslim Minority Affairs, 30(4), 463-477.

Beydoun, K. A. (2018). American Islamophobia: Understanding the Roots and Rise of fear. University of California Press.

Bilici, M. (2010). Muslim ethnic comedy: Inversion of Islamophobia. In A. Shryock, Islamophobia/Islamophilia (Beyond the Politics of Enemy and Friend). Indiana University Press. 195-208.

Campisano, F. (2016). A Case Study of Comedian Hannibal Buress and Humour as an agent for change. Elon Journal. 25.

Micu, A. (2012). Humour Alert: Muslim and Arab stand-up comedy in post 9/11 United States (Doctoral Dissertation, Texas A \& M University).

Schiffrin, D. (1994). Approaches to discourse (Vol. 8). Oxford: Blackwell.

Schwarz, J. (2009). Linguistic Aspects of verbal humour in stand-up comedy.

Selim, Y. F. (2014). Performing Arabness in Arab American Stand-up Comedy. American, British and Canadian Studies Journal, 23 (1), 77-92.

Shellnutt, K. (2017, April 30). Meet Hassan Minhaj Muslim Comedian who roasted Donald Trump in front of reporter. THE WASHINGTON POST.

Silverman, D. (2000). Analyzing talk and text. Handbook of qualitative research, 2(0), 821834.

Thonnart, M. (2016). American Muslim and Contemporary Hahahalal Comedy. Islam and Christian Muslims Relations, 27 (2), 133-151.

Tuček, J. (2008). Power through Humour: Thomas king strategies for decolonizing Canada. Wikipedia contributors (n.d.). Maz Jobrani. Retrieved from https://en.wikipedia.org/wiki/Maz_Jobrani

Wikipedia contributors (n.d.). Muhammad Amer. Retrieved from https://en.wikipedia.org/wiki/Mohammed_Amer

Zimbardo, Z. (2012). Cultural politics of humour in (de) normalizing Islamophobic stereotypes. Islamophobia Studies Journal, 2 (1), 59-81. 